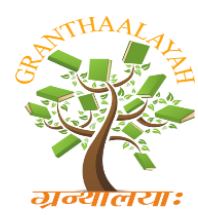

INTERNATIONAL JOURNAL OF RESEARCH GRANTHAALAYAH

A knowledge Repository

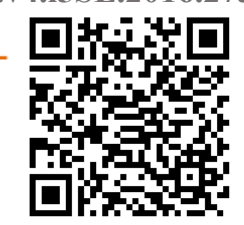

Social

\title{
RELATION BETWEEN EMOTIONAL INTELLIGENCE AND REASONING ABILITY OF HIGHER SECONDARY STUDENTS
}

\author{
C. Daisy Nambikkai ${ }^{* 1}$, Dr. A.Veliappan ${ }^{2}$ \\ ${ }^{*}$ Reasearch Scholar, Department of Education, Manonmaniam Sundaranar University, \\ Tirunelveli, Tamil Nadu, INDIA \\ ${ }^{2}$ Research Guide, Department of Education, Manonmaniam Sundaranar University, Tirunelveli, \\ Tamil Nadu, INDIA
}

\begin{abstract}
The present study aims to find out the relationship between emotional intelligence and reasoning ability of the higher secondary students. Among the population, 724 samples of higher secondary students were selected randomly from Puducherry region. Findings of the study were i) significant difference is found between male and female higher secondary students in their reasoning ability in science on analogical reasoning, classification as reasoning, eclectic reasoning, deductive reasoning and inductive reasoning. ii) Significant difference is found between male and female higher secondary students in their emotional intelligence on intrapersonal awareness. iii) Significant difference is found among government, aided and unaided schools of higher secondary students in their reasoning ability in science on classification as reasoning and eclectic reasoning. iv) Significant difference is found among government, aided and unaided schools of higher secondary students in their emotional intelligence on intrapersonal awareness, interpersonal awareness, intrapersonal management and interpersonal management. v) there exists significant positive relationship between reasoning ability in science and emotional intelligence of higher secondary students.
\end{abstract}

Keywords:

Reasoning ability, Science and Emotional intelligence.

Cite This Article: C. Daisy Nambikkai, and Dr. A.Veliappan, "RELATION BETWEEN EMOTIONAL INTELLIGENCE AND REASONING ABILITY OF HIGHER SECONDARY STUDENTS" International Journal of Research - Granthaalayah, Vol. 4, No. 5: SE (2016): 98105.

\section{INTRODUCTION}

Education is the process by which society deliberately transmits accumulated knowledge, skills and values from one generation to another. In the words of Rousseau, "Education is the child's development from within". According to Pestalozzi, "Education is natural, harmonious and progressive development of man's innate powers". 
Reasoning is a word used to describe the mental cognition of cause and effect relationships. It may be the prediction of an event from an observed cause, or the inference of a cause from an observed event. Accuracy is the criterion of good reasoning.

\section{REASONING ABILITY IN SCIENCE}

Reasoning plays a significant role in making adjustment to present complicated world of relationship and material. Reasoning ability controls individual's cognitive activities and it influences the behaviour and personality. The absence of the reasoning ability leads to improper development of mind and body. Analyzing the importance of reasoning, Garrott (1968), defines reasoning as "stepwise thinking with a purpose or goal in mind. Reasoning is looked as more serious and complex mental process which needs a well -organized brain and deliberate effort".

Emotional intelligence is a relatively new and growing area of behavioural investigation, having matured recently with the aid of lavish international media attention. Emotional intelligence refers to the competence to identify and express emotions, understand emotions, assimilate emotions in thought, and regulate both positive and negative emotions in the self and in others.

\section{EMOTIONAL INTELLIGENCE}

Emotional intelligence promotes understanding, stability and harmony in human relationship; it also helps to create balance in a person's education. Emotional intelligence skills in education also motivate students to achieve higher learning goals and broaden their personal development.

The psychologists, R.Wylie and S.Burus (1979), stated that students who are emotionally stable feel more confident of their abilities and, thus, they are more successful in their lives. Emotional intelligence is the intelligence that is in a person associated with the level of ability to deal with other people, feelings, and daily social environment. Individuals with high levels of intelligence are the people who are able to control their feelings of stress they faced, so that it does not disable the ability to think wisely. Normally, individuals with high levels of emotional intelligence will be successful in their career and life.

\section{REVIEW OF RELATED LITERATURE}

Sekar (2013) findings showed that there is significant difference between the higher secondary boys and girls of biology group and computer group students in reasoning ability.Bandhana and Sharma (2012) there is no significant sex differences in reasoning ability among secondary school students, and there is significant differences in reasoning ability among students studying in government and private secondary schools. Kalhotra (2014) result reveals that gender has no significant effect on mean difference of any of the components of the emotional intelligence. Girls are more emotional than boys because girls have higher emotional tendency than boys. MeenuYadav (2014) there is no significant relationship between the emotional intelligence of senior secondary class students of government and non-government schools. The emotional intelligence of senior secondary class students of Government and non-government schools (boys \&girls) are found to be below average. Mehar and Sekri (2013) findings suggested that there was significant difference in emotional intelligence of male and female science students. 


\section{METHOD ADOPTED FOR THE STUDY}

The investigator adopted survey method and used the Reasoning Ability in Science Scale (RASS) prepared and validated by Dr.Anuradha Joshi and Bhuban Chandra Mahapatra (1994). It consists of 30 items with six dimensions namely analogy, classification, eclectic, deductive and inductive reasoning. Emotional Intelligence Inventory (EII) prepared and validated by Mangal and Shubra Mangal (2009). It consists of 100 items with four dimensions namely intrapersonal awareness, interpersonal awareness, intrapersonal management and interpersonal management.

\section{DATA ANALYSIS}

Ho1: There is no significant difference between male and female higher secondary students in reasoning ability in science

Table 1: Difference between male and female higher secondary students in reasoning ability in science

\begin{tabular}{|l|l|l|l|l|l|l|}
\hline \multirow{2}{*}{$\begin{array}{l}\text { Dimensions of Reasoning } \\
\text { ability in science }\end{array}$} & \multicolumn{2}{|l|}{ Male(N-427) } & \multicolumn{2}{l|}{ Female(N-297) } & Calculated \\
\cline { 2 - 7 } & 't' value & Remarks \\
\hline Analogical reasoning & 2.66 & 1.62 & 2.35 & 1.33 & 2.81 & $\mathrm{~S}$ \\
\hline Classification as reasoning & 3.02 & 1.64 & 2.58 & 1.34 & 3.97 & $\mathrm{~S}$ \\
\hline Eclectic reasoning & 2.50 & 1.62 & 2.12 & 1.03 & 3.86 & $\mathrm{~S}$ \\
\hline Deductive reasoning & 2.28 & 1.60 & 1.78 & 1.28 & 4.62 & $\mathrm{~S}$ \\
\hline Inductive reasoning & 2.10 & 1.86 & 1.39 & 1.31 & 6.05 & $\mathrm{~S}$ \\
\hline $\begin{array}{l}\text { Reasoning ability } \\
\text { science (Total) }\end{array}$ & 12.65 & 6.69 & 10.23 & 3.97 & 6.09 & $\mathrm{~S}$ \\
\hline
\end{tabular}

S-Significant

It is inferred from the above table that the calculated ' $t$ ' value is greater than the table value (1.65) for df of 722, at 5\% level of significance. It shows that there is significant difference between male and female higher secondary students received their reasoning ability in science on analogical reasoning, classification as reasoning, eclectic, deductive and inductive reasoning.

Ho2: There is no significant difference between male and female higher secondary students in emotional intelligence 
Table 2: Difference between male and female higher secondary students in emotional intelligence

\begin{tabular}{|c|c|c|c|c|c|c|}
\hline \multirow{2}{*}{$\begin{array}{l}\text { Dimensions of Emotional } \\
\text { Intelligence }\end{array}$} & \multicolumn{2}{|c|}{ Male(N-427) } & \multicolumn{2}{|c|}{ Female(N-297) } & \multirow{2}{*}{$\begin{array}{l}\text { Calculated } \\
\text { 't' value }\end{array}$} & \multirow[t]{2}{*}{ Remarks } \\
\hline & Mean & SD & Mean & SD & & \\
\hline Intrapersonal awareness & 13.26 & 3.37 & 13.86 & 2.90 & 2.54 & $\mathrm{~S}$ \\
\hline Interpersonal awareness & 12.82 & 3.18 & 13.21 & 3.24 & 1.61 & NS \\
\hline Intrapersonal management & 14.19 & 4.81 & 13.66 & 2.70 & 1.89 & NS \\
\hline Interpersonal management & 13.28 & 3.38 & 13.68 & 3.06 & 1.66 & NS \\
\hline Emotional intelligence (Total) & 53.17 & 8.86 & 54.37 & 8.27 & 1.87 & NS \\
\hline
\end{tabular}

S-Significant NS-Not significant

It is inferred from the above table that the calculated ' $t$ ' value is greater than the table value (1.65) for df of 722, at 5\% level of significance. It shows that there is significant difference between male and female higher secondary students received their reasoning ability in science on intrapersonal awareness. But there is no significant difference on interpersonal awareness, intrapersonal management, and interpersonal management.

Ho3: There is no significant difference among government, aided and unaided schools higher secondary students in reasoning ability in science

Table 3: Difference among government, aided and unaided schools higher secondary students in reasoning ability in science

\begin{tabular}{|c|c|c|c|c|c|c|}
\hline $\begin{array}{l}\text { Dimensions of } \\
\text { Reasoning } \\
\text { ability } \\
\text { science }\end{array}$ & Categories & $\begin{array}{l}\text { Source of } \\
\text { variance }\end{array}$ & $\begin{array}{l}\text { Sum of } \\
\text { squares }\end{array}$ & MSV & F-value & Remarks \\
\hline $\begin{array}{l}\text { Analogical } \\
\text { reasoning }\end{array}$ & $\begin{array}{l}\text { Government } \\
\text { Aided } \\
\text { Unaided }\end{array}$ & $\begin{array}{l}\text { Between } \\
\text { Within }\end{array}$ & $\begin{array}{l}5.45 \\
1648.82\end{array}$ & $\begin{array}{l}2.73 \\
2.29\end{array}$ & 1.19 & NS \\
\hline $\begin{array}{l}\text { Classification as } \\
\text { reasoning }\end{array}$ & $\begin{array}{l}\text { Government } \\
\text { Aided } \\
\text { Unaided }\end{array}$ & $\begin{array}{l}\text { Between } \\
\text { Within }\end{array}$ & $\begin{array}{l}44.11 \\
1671.33\end{array}$ & $\begin{array}{l}22.06 \\
2.32\end{array}$ & 9.52 & $S$ \\
\hline $\begin{array}{l}\text { Eclectic } \\
\text { reasoning }\end{array}$ & $\begin{array}{l}\text { Government } \\
\text { Aided } \\
\text { Unaided }\end{array}$ & $\begin{array}{l}\text { Between } \\
\text { Within }\end{array}$ & $\begin{array}{l}13.84 \\
1443.84\end{array}$ & $\begin{array}{l}6.92 \\
2.00\end{array}$ & 3.46 & $S$ \\
\hline $\begin{array}{l}\text { Deductive } \\
\text { reasoning }\end{array}$ & $\begin{array}{l}\text { Government } \\
\text { Aided } \\
\text { Unaided }\end{array}$ & $\begin{array}{l}\text { Between } \\
\text { Within }\end{array}$ & $\begin{array}{l}1.45 \\
1617.67\end{array}$ & $\begin{array}{l}0.72 \\
2.24\end{array}$ & 0.32 & NS \\
\hline
\end{tabular}




\begin{tabular}{|c|c|c|c|c|c|c|}
\hline $\begin{array}{l}\text { Inductive } \\
\text { reasoning }\end{array}$ & $\begin{array}{l}\text { Government } \\
\text { Aided } \\
\text { Unaided }\end{array}$ & $\begin{array}{l}\text { Between } \\
\text { Within }\end{array}$ & $\begin{array}{l}1.11 \\
2077.97\end{array}$ & $\begin{array}{l}0.56 \\
2.88\end{array}$ & 0.19 & NS \\
\hline $\begin{array}{l}\text { Reasoning } \\
\text { ability in } \\
\text { science(Total) }\end{array}$ & $\begin{array}{l}\text { Government } \\
\text { Aided } \\
\text { Unaided }\end{array}$ & $\begin{array}{l}\text { Between } \\
\text { Within }\end{array}$ & $\begin{array}{l}97.57 \\
24732.42\end{array}$ & $\begin{array}{l}48.79 \\
34.30\end{array}$ & 1.42 & NS \\
\hline
\end{tabular}

S-Significant, NS-Not significant df $(2,722)$, the table value of ' $f$ ' is 2.99

From the above table shows that there is significant difference among government, aided and unaided schools of higher secondary students in their classification as reasoning, eclectic reasoning. But there is no significant difference on analogical reasoning, deductive reasoning, and inductive reasoning.

Ho4: There is no significant difference among government, aided and unaided schools higher secondary students in Emotional intelligence

Table 4: Difference among government, aided and unaided schools higher secondary students in emotional intelligence

\begin{tabular}{|l|l|l|l|l|l|l|}
\hline $\begin{array}{l}\text { Dimensions of } \\
\text { Emotional } \\
\text { intelligence }\end{array}$ & Categories & $\begin{array}{l}\text { Source of } \\
\text { variance }\end{array}$ & $\begin{array}{l}\text { Sum of } \\
\text { squares }\end{array}$ & MSV & F-value & Remarks \\
\hline $\begin{array}{l}\text { Intrapersonal } \\
\text { awareness }\end{array}$ & $\begin{array}{l}\text { Government } \\
\text { Aided } \\
\text { Unaided }\end{array}$ & Between & 247.05 & 123.52 & 12.46 & $\mathrm{~S}$ \\
\hline $\begin{array}{l}\text { Interpersonal } \\
\text { awareness }\end{array}$ & $\begin{array}{l}\text { Government } \\
\text { Aided } \\
\text { Unaided }\end{array}$ & Between & 273.20 & 136.60 & 13.70 & $\mathrm{~S}$ \\
\hline $\begin{array}{l}\text { Intrapersonal } \\
\text { management }\end{array}$ & $\begin{array}{l}\text { Government } \\
\text { Aided } \\
\text { Unaided }\end{array}$ & Between & 103.08 & 51.54 & 3.09 & $\mathrm{~S}$ \\
\hline $\begin{array}{l}\text { Interpersonal } \\
\text { management }\end{array}$ & $\begin{array}{l}\text { Government } \\
\text { Aided } \\
\text { Unaided }\end{array}$ & Between & 289.35 & 144.68 & 14.11 & $\mathrm{~S}$ \\
\hline $\begin{array}{l}\text { Emotional } \\
\text { intelligence(Total) }\end{array}$ & $\begin{array}{l}\text { Government } \\
\text { Aided } \\
\text { Unaided }\end{array}$ & Between & 3198.00 & 1599.00 & 22.66 & $\mathrm{~S}$ \\
\hline
\end{tabular}

S-Significant df $(2,722)$, the table value of ' $F$ ' is 2.99

From the above table shows that there is significant difference among government, aided, unaided schools higher secondary students in their intrapersonal awareness, interpersonal awareness, intrapersonal management and interpersonal management.

Ho5: There is no significant relationship between reasoning ability in science and emotional intelligence of higher secondary students 
Table 5: Relationship between reasoning ability in science and emotional intelligence of higher secondary students

\begin{tabular}{|l|l|l|l|l|}
\hline $\begin{array}{l}\text { Reasoning ability Vs Emotional } \\
\text { intelligence }\end{array}$ & $\begin{array}{l}\text { Calculated } \\
\text { value }\end{array}$ & $\mathbf{N}$ & Table value & Remarks \\
\hline Intrapersonal awareness & 0.154 & & & $\mathrm{~S}$ \\
Interpersonal awareness & 0.136 & & & $\mathrm{~S}$ \\
Intrapersonal management & 0.124 & 724 & 0.0619 & $\mathrm{~S}$ \\
Interpersonal management & 0.202 & & $\mathrm{~S}$ \\
\hline Emotional intelligence (Total) & 0.214 & & & $\mathrm{~S}$ \\
\hline
\end{tabular}

S-Significant df 2,722

From the above table, it is inferred that the calculated 0.0619 value is greater than the table value at $5 \%$ level of significance. There is significant relationship between reasoning ability in science and emotional intelligence of higher secondary students.

\section{FINDINGS}

1) Significant difference is found between male and female higher secondary students in their reasoning ability in science on analogical reasoning, classification as reasoning, eclectic reasoning, deductive reasoning and inductive reasoning. The male students have received better reasoning ability in science than female students.

2) Significant difference is found between male and female higher secondary students in their emotional intelligence on intrapersonal awareness. The female students received better reasoning ability in science on intrapersonal awareness than the male students. But there is no significant difference on interpersonal awareness, intrapersonal management and interpersonal management.

3) Significant difference is found among government, aided and unaided schools of higher secondary students in their reasoning ability in science on classification as reasoning and eclectic reasoning. The higher secondary students of aided schools are found to be significantly better receiving reasoning ability in science on classification as reasoning and eclectic reasoning. But there is no significant difference on analogical reasoning, deductive reasoning, and inductive reasoning.

4) Significant difference is found among government, aided and unaided schools higher secondary students in their emotional intelligence on intrapersonal awareness, interpersonal awareness, intrapersonal management, and interpersonal management. The higher secondary students of government schools are found to be significantly better receiving emotional intelligence on intrapersonal awareness, interpersonal awareness. The higher secondary students of aided schools are found to be significantly better receiving emotional intelligence on intrapersonal management, and interpersonal management. 
5) There exists significant positive relationship between reasoning ability in science and emotional intelligence of higher secondary students.

\section{INTERPRETATION OF THE STUDY}

The male students have received better reasoning ability in science than female students. This may be due to the fact that the male students having much curious to learn about science and scientific facts. Male students usually getting opportunity to go to the science exhibitions and science fairs than female students.

The female students received better emotional intelligence on intrapersonal awareness than the male students. This may be due to the fact that the female students gain much guidance programme from the school set up and also from the family members especially after puberty stage. Frequently the parents are giving advice to the female children for getting intrapersonal awareness. So they are aware of their appropriately.

The higher secondary students of aided schools are found to be significantly better receiving reasoning ability in science on classification as reasoning and eclectic reasoning. This may be due to the fact that aided school students are provided very good library facilities and encouraged by the teachers for wide reading, so that the students got wider thinking and reasoning power. Unaided school students are encouraged to get high score in annual examination, then only they can get adequate level admission for the next year. Government school students are not supervised by their parents because of poverty and not properly guided by their teachers also.

The higher secondary students of aided schools are found to be significantly better receiving emotional intelligence on interpersonal awareness, intrapersonal management and interpersonal management. This may be due to the fact that the aided school teachers and students are very much achievement oriented and developing good personal management towards others. So that they are aware of thyself and develop conducive managerial intelligence towards others. But government school students are not properly guided by their parents and teachers to become an emotionally intelligent person. Unaided school students are not having attachment towards others. Because they are fully motivated towards achievement in the academic side.

Each and every action having equal and opposite reaction. Whatever the incident we hear or happen in front of us the person must reason out things. After analysing the situation in their mind, they can become balanced and get emotionally intelligent.

\section{CONCLUSION}

On the basis of the findings, the investigator tries to conclude that the emotional intelligence is very imperative to the students. There is relation between emotional intelligence and the reasoning ability of the higher secondary students. Emotional intelligence is the ability to carry out accurate reasoning focused on emotions and the ability to use emotions and emotional knowledge to enhance thought. The students with well-developed emotional skills and reasoning ability are more likely to content and effective in their lives, mastering the habits of mind that foster their own productivity. 


\section{REFERENCES}

[1] Atkinson,J.Myron and R.WillBurnell , "Science Education" Encyclopedia of Educatonal Research.4th ed.,1192-1205.

[2] Crow,L.D.andCrow,A(1973).Educational Psychology,3rd Indian reprint, Eurasia Publishing House,New Delhi.

[3] Ennis, R. H. (1987). Taxonomy of critical thinking skills and dispositions. In J. B. Baron and R. J. Sternberg (Eds.), Teaching Thinking Skills: Theory and Practice, New York: Freeman (p 9-26).

[4] Kahn, P. H., Jr. (1997). Children's moral and ecological reasoning about the Prince William Sound oil spill. Developmental Psychology. 33. 1091-1096.

[5] Sodian, B., \& Bullock, M. (2008). Scientific reasoning - where are we now? Cognitive Development, 23(4), 431-434. 